\title{
Rhetoric of Political Repression in Nigerian Newspaper Reports: The Critical Discourse Analysis Perspective
}

\author{
Chinwe Ezeifeka, Nnamdi Azikiwe University,PMB 5025, Awka, Anambra State, Nigeria
}

chiezeifeka@gmail.com

\begin{abstract}
This paper explores the rhetoric of political repression in the Guardian newspaper reports of June and July 2008 Nigerian Union of Teachers' (NUT) nationwide strike embarked upon to demand a special salary scale. It specifically focuses on language use in the newspaper reports on this issue as an indication of the media's seemingly transparent but inherently ideological reportage, projecting the "truth" of the political power elite and repressing the views of the less dominant whose interest the media supposedly champion. Using three theoretical perspectives, critical discourse analysis which takes the side of the less privileged to question the textual representations of the power elite; systemic functional grammar which studies the meaning relations residing in the systemic patterns of textual choices of language users; and argumentation theory used to determine the various appeals made in the reports to argue the case of the various stakeholders, the paper highlights the truism of the media's apparent neutrality in their reports. The various forms of rhetoric, located in the unsaid, attribution to sources, manipulation of intertextual resources and gatekeeping ideology were among the strategies employed in the newspaper reportage. In a total of forty-six reports, spanning thirty-six days the strike lasted,it was found that the newspaper deliberately avoided an editorial on the strike thereby locating its ideology in the 'unsaid'. It also, in connivance with the dominant power elite, manipulated the wordings of the Constitution of the Federal Republic of Nigeria 1999 using ad hoc argument and subtle persuasion to quash the demands of the NUT, thus exploiting intertextual resources ('the already-said') to support a suppressive regime. These representations portray the newspaper's gate keeping-ideology -as partial and selective in its reports. It also implicates the newspaper as adopting the 'ideology of silence' and as reneging on its watchdog role as the champion of public interest.
\end{abstract}

Indexing terms/Keywords: rhetoric, political repression, newspaper reports, critical discourse analysis, power, ideology, press freedom

\section{Academic Discipline And Sub-Disciplines}

English Language studies, discourse analysis

\section{SUBJECT CLASSIFICATION}

English Language Studies: Library of Congress Classification

\section{TYPE (METHOD/APPROACH)}

Textual analysis, critical discourse analysis,

\section{Council for Innovative Research}

\author{
Peer Review Research Publishing System
}

Journal: Journal of Social Sciences Research

Vol. 10, No. 1 


\section{INTRODUCTION}

The role of the media in shaping public opinion and setting the agenda for contemporary society in terms of communication and information dissemination raise questions on how they fulfill their societal obligation as watchdog of public interest. A number of researches have delved into media representation of events and have come to the conclusion that the mediated nature of these representations have led to distortion, misrepresentation, emphasizing particular points of view and relegating others that do not conform with favoured stance (Fairclough, 1995; Mey, 2001; O'Halloran, 2007). This paper is a contribution to this debate and its special focus is on the apparent neutrality of the Nigerian media as well as the truism in the popular expression about press freedom.

It may be expedient to start this discussion with the key words in this topic in order to establish their relevance to the thesis pursued in this paper. The concepts which form the crux of our argument include "rhetoric", "political repression", and "newspaper reports". The term rhetoric has both classical and modern connotations which may be salutary as well as pejorative. Aristotle, the father of classical rhetoric defined it as "the art of observing in a given situation the available means of persuasion" (Carlin \& Payne, 1995:440). Other scholars like Crystal (2003:400) and Trail (2004: x) see it as "the use of written language in an attempt to persuade".

However, in modern times, people equate rhetoric with trickery, the use of language to deceive and manipulate, applying unethical means to sway an audience and gain unmerited support or consensus. Rhetoric in this pejorative sense connotes being smart or clever in using words as propaganda machinery to hide our true but repressive agenda on the audience. In critical discourse analysis (CDA), which is the perspective applied to the present study, the term rhetoric carries a negative connotation. According to Fairclough (1995:153), rhetoric is to consciously use language as a game, playing with words, "parodying an alien discourse for strategic effects".

This brings us to the second concept of our topic, "political repression". Repression is a term used by Mey (2001) to denote all forms of oppression, suppression, marginalization, under-representation, and denial of social rights and privileges which characterize many if not all institutionalized discourses and discursive practices. Mey (2001:297) was particularly concerned with "linguistic repression", which he described as "a subtle but pernicious form of social control", the use of language to institutionalize inequities and to represent only the "truth" of the dominant power while those with less access to social power and privileges are relegated and their views are never represented in discourse. Mey is advocating for a type of linguistics that is "emancipatory", that can represent all subjects equally regardless of social or political positions. The epithet political as used in our topic relates the concept of repression to the power elite, those responsible for authority and control of material and human resources in a particular social milieu; in fact, those responsible for piloting the affairs of the state.

Relating the concept of linguistic repression to our third keyword, "newspaper reports", we highlight the responsibility of the print media to its teeming audience of appropriate and judicious use of language in information dissemination. The media is regarded as the repository of public discourse, the custodian of the means of communication and information, the medium of social power, an "ideological state apparatus" (Watson and Hill, 2006:129) used by the power elite to exert social control through persuasion and manufacture of consent (hegemony), and by this means enthrone their ideologies. The media is said to 'mystify' relations of domination in the community of practice and to project a view that language use in the media is transparent and truthful (Fairclough, 1995:25). Traditionally, they are referred as 'the fourth estate of the realm' (Chambers, 2007:524; Watson \& Hill 2006:104), that is, the watchdog of society, the champion of public interest and a medium for the surveillance of the power elite on behalf of, and in the interest of the powerless.

Having established our conceptual framework, it is equally germane to state our major concerns in this work. We are concerned with how the Guardian newspaper, a privately-owned Nigerian newspaper used as our case study, represented the June and July 2008 nation-wide industrial action by the Nigerian Union of Teachers (NUT) to demand for a special salary scale popularly known as Teachers' Special Salary Scale (TSS). We are concerned with how the newspaper reports on the issue advanced the cause of the common citizens of this country, the public primary and secondary school teachers, how the newspaper served this section of public interest in prioritizing what news to give prominence through its editorial and other news items, and how it mediated in the various arguments and strategies of repression contrived by the power elite. The work poses the following questions: what amount of coverage was given the strike by the newspaper? What are those things that should have been reported but were not? What arguments were put forward by the political elite to quash the TSS and how did the newspaper corroborate these arguments? What other rhetorical appeals were exploited in the reports? What ideological positions did the newspaper project by the stance it took in these reports? These questions locate the present study within the research perspective of critical discourse analysis (CDA).

\section{THEORETICAL FRAMEWORK}

The work is hinged on an integration of four analytical models which include critical discourse analysis (CDA), Fairclough's implicit and explicit textual content model, Halliday's systemic functional linguistics and the rhetoric of argumentation. We shall discuss these in turn as they relate to the present study.

\section{Critical Discourse Analysis}

CDA is an interdisciplinary research perspective which connects language use to concepts such as power, ideology, and social practice. Leading scholars in this enterprise include: Michel Foucault, Roger Fowler, Robert Hodge, Gunther Kress, Tony Trew, Norman Fairclough, Ruth Wodak, Teun van Dijk, Allan Luke, Siegfried and Margaret Jager, Theo van Leeuwen and a host of others (Wodak and Busch, 2004). CDA advocates the scrutiny of texts to reveal how language 
can be structured to become a veritable instrument of propaganda, deceit, manipulation, marginalization, oppression, under-representation and misrepresentation among others. CDA is regarded as a perspective of doing scholarship, a research paradigm which takes the side of the oppressed to demystify texts in order to reveal dominant ideological positions and bring them up for scrutiny. (Fairclough 1995; van Dijk, 2005; Wodak, 2005; Luke 2008). It presupposes that some social institutions and ideological positions pose as gate-keepers of mastery of discourse resources; such that particular portrayals of social and biological worlds appear as given, commonsensical, normal, taken-for-granted and natural. In this way, oppression, repression, manipulation, and marginalization can go unchallenged if the text is not critically analyzed to reveal the underlying power relations and dominant ideologies (Luke, 2008). Texts, in CDA, have been described as 'sites of struggle' (Wodak, 2005: 10-11), sites in which contending ideological positions struggle with one another for dominance.

CDA conceptualizes power in two ways: firstly, as asymmetries between participants in discursive events. Secondly, it relates the concept of power to unequal capacity to control how texts are produced, distributed and consumed in particular sociocultural contexts. These inequities determine the shapes of texts, that is, the 'orders of discourse' that tend to construe discursive practices in dominance (fairclough, 1995). Power in CDA does not therefore manifest as physical coercion but as ideological power, the capacity to dominate through consensus and manufacture of consent or "hegemony" (Fairclough,1995:75; Jones and Wareing, 2000:34). According to CDA proponents, language mediates social practice and dominant ideologies and the media is an institutionalized channel of this mediation. The media prioritizes information dissemination and act as gatekeepers, deciding what news to give prominence and those to relegate to the background. The case under review offers a test case for this assertion. In what follows, Fairclough (1995) gives an insight into how it is possible for the media to engage in this gatekeeping by making their content either explicit or implicit for strategic effects.

Fairclough (1995:24) argues that "ideology resides in the unsaid (implicit content), the already-said or the preconstucted" (explicit content/textual practice/intertextuality). Implicit propositions, he claims, refer to issues which the writer or speaker takes for-granted as natural and as an order of discourse and which the listener or reader is called upon to acknowledge as the background knowledge or presuppositions of particular social settings and need not be stated explicitly in discourse. They are viewed as ideological because of the tendency to project the presuppositions of the dominant world view. The "already-said" or explicit content (the preconstructed) can also be exploited by the dominant power as an authority or warrant to legitimize their suppressive and obnoxious regimes. Prior texts and the resources of intertextuality may form the basis for socially-acceptable modes of marginalization, oppression and relegation to subservience of the less dominant.

Fairclough (1995) advocates proper scrutiny of prior texts and discourses upon which present texts and discourses are based in order to reveal these hidden suppressions. In our study, the Constitution of the Federal Republic of Nigeria 1999 was quoted as an authority against the illegality of the teachers' demand for the special teachers' salary structure (TSS). We shall in our analysis present the relevant section of the constitution implicated in this intertextual manipulation of the arguments and rhetorical appeals used by the power elite to quash the demands of the teachers and how the newspaper reports corroborated this stance.

\section{Systemic Functional Grammar}

The systemic functional theory has been recognized by many scholars working in the area of CDA as a powerful explanatory and evaluative framework for analyzing language use in context. This framework sees discourse as a strategic meaning-making and text-forming resource which enables people to accomplish their purposes in life, make sense of their experiences in the world and act out their personal and group relationships (Halliday and Matthiessen, 2004). The fundamental concept of the theory is that the language system provides the language user with a rich inventory of alternative choices which are in paradigmatic relationship with one another. For instance, the choice between the words 'miscreants' 'rebels' 'striking teachers', 'honest employees', 'law-abiding citizens', 'hooligans' may be applied to the same group depending on the position of the speaker or writer and the function of that choice in the context. This language use as a system of choice has been described by Halliday as 'the potential' and 'the actual' (Halliday, 1978:40; Eggins, 2004:20), the former referring to the total meaning potentials from where a speaker chooses one linguistic item from among a range of options open to them (systemic), and the latter to the actual choices including the function of the choice in a given context of situation (functional). This concept of "choice" underlies the critical analytic approach to the interpretation of texts. The analyst is concerned with why speakers/writers choose certain linguistic items and not others and what social purpose such choices are set to accomplish.

Language, in systemic theory, is arranged in three levels or strata: the contextual stratum comprising register variables of field, tenor and mode. The semantic stratum, that is, the meaning component, comprises the ideational, interpersonal and textual metafunctions or meaning potentials; while the lexicogrammatical stratum which operates at the level of wording includes transitivity, mood and theme. (For detailed explication of this theory, see Halliday,1978; Halliday and Matthiessen, 2004). For our purposes, we looked at the lexicogrammatical choices made by the newspaper of certain process types and the resources of clause complexing to achieve certain strategic effects in the reports under review. The paper puts a query on the role of the Sayer and Behaver in the newspaper headlines and reports, how the newspaper divests itself of direct verbalizations in favour of the NUT and assigns this role to other sources thereby remaining aloof in apparent neutrality. These process choices in the transitivity system buttress the newspaper's deliberate but consistent avoidance of responsibility and playing to the gallery. 


\section{Argumentation Theory}

We also applied Aristotelian model of argumentation because of the use made by the newspaper of the various appeals related to this model. Aristotle, the classical Greek thinker and philosopher was the first to describe the three ethical appeals a writer or speaker could draw on to manufacture consent in their audience, namely: appeal to the audience rationality - "logos", appeal to the audience emotions - "pathos" and appeal based on the writer's/speaker's character/credibility - "ethos" (Carlin and Payne, 1995:443-446). To appeal to the audience rationality, emotions and trust, the writer employs sound argument, logical reasoning process and credible persuasive strategies. In our textual data, these appeals were exploited by reference to the constitution to support the argument that the Federal Government lacked the constitutional powers to implement the TSS, through persuasion which has been proved to be the most effective means of social control, in fact, more efficacious than coercion (Wareing, 2000), and by attribution of credible opinions to sources or authorities which the audience would consider trustworthy (Carlin and Payne, 1995:343). We shall direct our analysis to proving the veracity of these and other arguments in this study.

\section{METHODOLOGY AND TEXTUAL DATA}

This work attempts to investigate the rhetoric used by the Guardian Newspaper in its reports of the June and July 2008 Nigerian Union of Teachers' (NUT) nationwide strike. The Guardian was selected because, being a privately-owned newspaper, it is assumed to be free from much government influence. The issue at stake was the demand by primary and secondary school teachers under the aegis of the NUT of a special and enhanced salary scale popularly called "Teachers' Salary Scale" (TSS). This body wanted the Federal Government to issue a circular mandating the various states to pay the TSS and also to subsidize the payments.

The strike that lasted for thirty-four days consisted of three days warning strike from June 11 to 13, 2008; and the strike proper from June 30 to July 30 . Out of a total number of thirty-six (36) editions of the newspaper representing the number of days the strike was to have been reported as shown in Table 1, twenty-eight (28) editions contain reports of the strike. There were no reports for six days, while two editions (7th and 11th July editions) were not available during the search for data. Our data corpora consisted of thirty-two reports relating to the issues raised by our research questions and selected from a total of forty-six reports on the strike.

\section{DATA ANALYSIS AND DISCUSSION}

Tables 1 and 2 present the coverage of the strike by the newspaper. Table 1 indicates the days the strike was reported vis-à-vis the number of days covered by the strike while Table 2 summarized the type of publications given the strike.

Table 1:Days Covered by the Strike versus Days the Strike was Reported

\begin{tabular}{|l|l|l|l|l|l|l|l|l|l|l|l|l|l|}
\hline \multicolumn{4}{|c|}{ Warning strike - June 11 - 132008} & \multicolumn{4}{|c|}{ Strike proper - June 30 - July 302008} \\
\hline Mon & Tue & Wed & Thur & Fri & Sat & Sun & Mon & Tue & Wed & Thur & Fri & Sat & Sun \\
\hline- & - & - & - & - & - & - & & 1 & 2 & 3 & 4 & 5 & 6 \\
\hline- & - & - & - & - & - & - & $(7)$ & $\mathbf{8}$ & $\mathbf{9}$ & 10 & $(11)$ & 12 & ${ }^{*} 13^{\star}$ \\
\hline- & - & 11 & 12 & ${ }^{*} 13^{\star}$ & 14 & & ${ }^{*} 14^{\star}$ & 15 & 16 & 17 & 18 & 19 & ${ }^{*} 20^{\star}$ \\
\hline- & - & - & - & - & - & - & ${ }^{\star} 21^{\star}$ & 22 & 23 & 24 & ${ }^{\star} 25^{\star}$ & 26 & 27 \\
\hline 30 & - & - & - & - & - & - & 28 & 29 & 30 & 31 & - & - & - \\
\hline
\end{tabular}

Key: Days the strike was reported: - (Bold) - 28days

No report days: - (Normal print and asterisked) - 6days

Days not sighted: - (enclosed in parenthesis) - 2days

Total number of days covered by the strike - 34days

Number of editions of the Newspaper the strike should have been reported - 36 editions.

Table 2:Summary of the Types of Publications on the Strike

\begin{tabular}{|l|l|}
\hline Type of Publication & Number of Occurrence \\
\hline News items (by the Newspaper reporters) & 44 \\
\hline Cover stories (by the editorial crew) & 2 \\
\hline Editorial (by the editorial crew) & Nil \\
\hline Total Number of Publications & $\mathbf{4 6}$ \\
\hline
\end{tabular}

The coverage of the strike was determined by the number of editorials, cover stories and news items published by the newspaper within the thirty-four days of the strike. Out of the forty-six (46) reports on the strike garnered from the various 
editions of the newspaper, forty-four (44) were news items, two (2) were cover stories. There was no editorial comment on the strike.

According to Chambers 21st Century Dictionary (2007:419), an editorial is "an article written by or on behalf of the editor of a newspaper or magazine, usually one offering an opinion on a current issue". A cover story, according to the Oxford Advanced Learners' Dictionary (2005:269) is "the main article in a magazine (or newspaper) usually advertised (as "cover story") or begun on the front cover" and we might add "which the magazine or newspaper takes as the topical issue that needs priority attention". News items are usually brought in by newspaper reporters and may be published on any page of the newspaper.

The absence of an editorial in the newspaper reports on the issue of the TSS aptly illustrates Fairclough's (1995:24) "implicit content", (the rhetoric of the unsaid). This apparent neutrality and aloofness seems calculated and deliberate since no sooner had the health workers announced their impending strike than the same newspaper editorial proclaimed in bold headlines "The Proposed Health Workers' Strike", and this on the same day the NUT strike was suspended. The editorial presented in strong attributive clauses the voice of the newspaper regarding its apprehension, and by extrapolation "our apprehension", of the devastating consequences of the health workers' strike while the teachers' strike was mentioned in passing as an embedded clause, an optional hypotactic element in the grammar (see italics in Text 1) which is not the nub of the argument.

\section{Text 1}

It is appalled ( $\mathrm{sic}$ ) that, amidst the strike by secondary and primary school teachers across the federation which is taking its toll on the economy after three weeks (more than four weeks!), health workers in the country are about to down tools in another round of strike and government in its usual manner is doing nothing about it. This is worrisome. We are apprehensive of the ugly consequences of a strike of that magnitude. Health sector strikes_are usually devastating ... (Editorial, 2008, July 30:18)

We also noted that the two cover stories recorded during the strike were subtly indicting on the teachers rather than projecting their interest. They were captioned "When Teachers insist on their Rewards on Earth..." (Ozioruva et al, 2008, July 18:30-31) and "Stakeholders Groan under the Effects of the Strike" ( ljediogor et al, 2008, July 26:51). Rather than present the issue at stake, the newspaper's stance in those reports was that of admonishment: teachers have abandoned their old identity of expecting their rewards in heaven and have allowed the "stakeholders" to "groan" under the yoke imposed on them by the uncompromising teachers. This stance projects the newspaper as discriminatory, selective, a partial gatekeeper in determining which report should be given prominence in an editorial or cover story and which should not. This gatekeeping ideology is a form of linguistic repression - exploiting access to the media of information to marginalize some social subjects and project others. It also implicates the newspaper as adopting an ideology of silence.

The newspaper combined the rhetoric of argumentation, attribution to sources and persuasion in its bid to project the 'truth' of the power elite and hide its ideological stance. Whereas the first was a logical appeal using the Constitution as the warrant to argue the illegality of the TSS (logos), the second was to belie its voice and gain credibility (ethos) while the third was an appeal to the emotions (pathos).

The following sample texts illustrate the appeal to the 1999 Constitution as a logical argument against the Federal Government's intervention in the issue of the TSS as reported by the newspaper. The newspaper, through the locutions of the three Education Ministers; the Minister of Education, the Minister of State for Education and the Minister of State for Education (II), used the 1999 Constitution as an authority to argue the illegality of issuing a circular to effect the implementation of the TSS by the Federal Government. Texts 2, 3 and 4 contain excerpts of these arguments.

\section{Text 2}

Education Minister, Dr Aja Nwachukwu said yesterday in Abuja that it is not the mandate of the Federal Government to fix salaries for teachers in the primary and secondary schools .... "The teachers don't have any basis to go on strike because education is on the concurrent list (in the Constitution) and by right, the states and local governments are in charge of secondary and primary education. ... (Onuorah et al, 2008, June 12:1-2)

\section{Text 3}

As the nation-wide teachers' strike entered another week, Minister of State for Education Dr Jerry Agada declared again yesterday that the Federal Government lacked the constitutional powers to impose a circular on states to compel them to implement the Teachers' Salary Scale (TSS) being demanded by the Nigerian Union of Teachers (NUT)... (Nwakaudu and Ogiji, 2008, July 22:112)

\section{Text 4}

Minister of State for Education (II) Mrs. Aisha Jibril Dukku has restated the Federal Government resolve not to impose the disputed Teachers Salary Scale (TSS) on the states ... Dukku argues that since education is on the concurrent list ... it will be wrong for the government to fix salaries for the states... (Abubakar and Awoyale, 2008, June 30:1).

In Text 5, we present the relevant sections of The Constitution of the Federal Republic of Nigeria 1999 which is the authority cited in this argument.

Text 5 Excerpts from the Constitution of the Federal Republic of Nigeria 1999 (pp.137-138) 
Second Schedule

Part li

\section{Concurrent Legislative List}

Item L: University, technological and post primary education.

29. Subject as herein provided, a House of Assembly shall have power to make laws for the state with respect to the establishment of an institution for the proposes of university, technological or professional education.

30 Nothing in the foregoing paragraph of this item shall be construed so as to limit the powers of a House of Assembly to make laws for the state with respect to technical, vocational, post primary, primary or other forms of education including the establishment of institutions for the pursuit of such education.

Reading the above excerpt from the 1999 Constitution between the lines, Paragraph 30 is what is being invoked and it is a kind of proviso to the preceding paragraph. We cannot question this provision off-handedly because the Constitution is the supreme law of the country. But we can question its application to the issue at stake, that is, the argument that the Federal Government issuing an enabling circular demanded by the NUT to approve a uniform salary for teachers in public primary and secondary schools was unconstitutional. We argue that issuing this circular would not have in any way negated the provisions of this paragraph of the Constitution. It would not have removed education from the concurrent list. It would only have made the Federal Government the arbiter, as the Minister suggested, in a national crisis in line with the provisions of the same Constitution, Section 18(1) captioned "Fundamental Objectives and Directive Principles of State Policy": "Educational Objectives".

Furthermore, the above assertion credited to the education ministers is an obvious contradiction to the claim by the Chairman of the Senate Committee on Education that "The TSS has been budgeted for" (Jimoh, et al, 2008, July 4:2) that "about N780 million has been appropriated in the supplementary budget" to implement the increment (Olayinka, 2008, June 14:2). The fact that the TSS was actually included in the budget was corroborated by the Minister of State for Education Dr Jerry Agada, who confirmed that the Federal Government included the TSS in the 2008 budget "for the purpose of fast-tracking the process of implementing the scheme for teachers in the country" and then subsequently discovered that the attempt was "wrong", "illegal" and a "mistake" (Nwakaudu and Ogiji, 2008, Tue July 22:112).

The above argument shows how rhetoric is constructed by the powerful to deceive, suppress and deprive the powerless of their basic sustenance. By a conscious and deliberate misapplication of the provisions of the 1999 Constitution, a considerable number of the country's population was forced to live below poverty level. This type of argument has been described as "ad-hoc" (Trail, 2004:8) or what Elly (2009) would call "ad-hoc concepts in ad-hoc contexts" - concepts or arguments invented on the spur of the moment to achieve spurious ends but which could be discarded or modified at will. This is linguistic repression in its most pernicious form. The copious diversionary strategy encoded in the above argument was indignantly but aptly captured in the statement credited to the founder and president of the Pan-Yoruba group, the Oodua People's Congress (OPC), Dr Fredrick Fasehun captioned:

Text 6: Teachers are Right to Demand Uniform Salary, says Fasehun (Oropo, 2008, July 27: 6).

Fasehun argued in vehement tones that the demand by public school teachers of uniform remuneration nationwide was in line with the Constitution. The newspaper writes:

\section{Text 7}

Fasehun reminded government of its responsibility as contained in the (second) chapter of the Constitution titled "Fundamental Objectives and Directive Principles of State Policy"... that "Government shall direct its policy towards ensuring that there are equal and adequate educational opportunities at all levels'. 'Since you cannot have education without teachers, and the Constitution directs government to guarantee equal educational opportunities at all levels, the Federal Government can comfortably promote equal remuneration for teachers nationally'... Describing as reasonable teachers' request that the Federal Government circulate a circular through all the levels of government about the new Teachers' Salary Structure, the OPC leader said, 'If the Federal Government used its wisdom to institute a uniform pump price through the Petroleum Equalization Fund to bridge the differences in the haulage of petroleum products across Nigeria, if the Federal Government can push a quota system in its appointments, if the Federal Government can dictate a national minimum wage, if the salaries of local government operatives, governors and legislators are uniform nationwide, the Federal Government should have no problem sending a memo that will guide payment of salaries for public school teachers...' (Oropo, 2008, July 27:6)

The above view, attributed to a source, should have been the stance of the newspaper editorial as the watchdog of the society rather than hiding under an informative mask. Still hiding under the canopy of attribution to other sources, the newspaper carried the views of the NLC President Mr Abdulwaheed Omar and Vice President, Alhaji Issa Aremu who argued pointedly the lack of awareness even among the power elite on the implications of this constitutional provision.

\section{Text 8}

... "The issues do not warrant the irreconcilability that is now evident in the position of the Federal Government and the NUT. Now that an impasse has ensured sic, leadership is required at the highest level to make the required compromises"... Omar said that the consideration now should be the immediate resumption of classes as opposed to the 
unhelpful rhetoric of some government officials especially the gratuitous lectures on Federalism". ("NUT Strike: NLC Urges YarAdua..." 2008, July 24:35-36).

\section{Text 9}

"the argument that the Federal Government cannot dictate to the states and local governments on what to pay the teachers since education was on the concurrent list was a complete abuse of the whole notion of the rule of law" He further stressed that "it also shows that virtually all the key actors of the government are ignorant of the country's constitution... "The Constitution did not say that the Minister of Education should be off-duty when the education sector is completely grounded. Nigeria operates a Federal System of government where the Federal, State and Local governments, though independent of each other, yet cannot operate without the other..." (Akhaine, 2008, July 28:8).

Table 3 below further illustrates the newspaper's deliberate avoidance of proffering explicit opinion on the issue of the TSS but passed the buck to other sources. The Table contains samples of the newspaper headlines exemplifying this rhetoric of "attribution to sources" contrived by such verbal processes as "urge", "say", "ask", "charge", "reveals" and behavioural process such as "lament", "groan" "decry" , thus assigning the responsibility of Sayer to other neutral participants. The expected intervention of government and/or criticisms against it were stated not as the view of the newspaper but as the view of "others" using the clause nexus of projection; (Halliday and Matthiessen, 2004:443, 604) - a projection of wording or locution which represents the contents of a verbal clause. These logical projections take the form of direct quote or report (the logical metafunction of clause complexing - an ideational component). This rhetoric has been effectively used by the newspaper to divest itself of direct responsibility to these locutions. This is also an indication of the ideology of silence in which the newspaper has been implicated. Silence means acquiescence and since the newspaper, in possession of the powerful instrument of communication and information dissemination, evades filling this gaping communicative lacuna in its own 'voice', it is implicated in projecting the views of the power elite.

Table 3: Samples of Headlines Showing Attribution to Sources

\begin{tabular}{|l|l|l|}
\hline & Date/Page & Headlines \\
\hline 1 & Thur. July 3, 2008:60 & Retreat reveals background of teachers' salary structure \\
\hline 2 & Sun. July 6 2008:7 & Why Private Schools Cannot Join Teachers' Strike, by Official \\
\hline 3 & Wed. July 9 2008:7 & Meet Teachers' Demand. NANs, others charge Govt. \\
\hline 4 & Thur. July 10, 2008:8 & Orji urges govt, teachers to dialogue \\
\hline 5 & Thur. July 10 2008:57 & Criticisms mount over govts' handling of teachers' strike \\
\hline 6 & Sat July 12 2008:4 & AC Asks Govt to Meet Teachers' Demand \\
\hline 7 & Sat July 12, 2008:5 & Court Did Not Restrain NUT from Picketing, Says Aturu \\
\hline 8 & Thur. July 17 2008:52 & AASU laments teachers' strike \\
\hline 9 & Sat July 19, 2008:4 & Mark, Sultan Urge Dialogue Over Teachers' Strike \\
\hline 10 & Wed July 23, 2008:80 & Labour, Senate panel decry govt's action over Teachers' strike \\
\hline 11 & Thur. July 24 2008:19 & Why the Minister of Education Must Go \\
\hline 12 & Sat July 26 2008:50-53 & Stakeholders Groan under the Effects of the Strike \\
\hline 13 & Sun July 27, 2008:6 & Teachers are Right to Demand Uniform Salary, says Fasehun \\
\hline 14 & Sun July 27 2008:6 & Citizens Write - Still on Teachers' Strike \\
\hline 15 & Thur. July 31 2008:59 & Don't politicize teachers' demands, school proprietor urges FG. \\
\hline
\end{tabular}

The power elite, through the medium of the newspaper, also resorted to the use of persuasion, the most powerful instrument of winning consent, to appeal to the emotions of the teachers/NUT to call off the strike. Using catchy headlines and touching verbalizations, the newspaper was able to contrive acquiescence from the teachers even without being granted their demands.

\section{Text 10:}

Placating teachers back to class (Popoola, Tues. July 22 2008:39)

The above headline was intended to appeal to the emotions of the teachers to return to work because of the use of the word "placate". It is however ironical that the first paragraph of the report under this catchy headline does not contain anything pacifying nor placating. It is obvious that the headline was deliberately catchy to appeal to the emotions while the report proper was indicting as this first sentence in the report would suggest:

Text 11 
The seed of the on-going teachers' strike was sown 19 years ago when they started to fight for a special Teachers Salary Scale (TSS). (Popoola, Tue. July 22 2008:39)

One is left in doubt as to how this statement is a means of "placating teachers back to class". Pathos was also invoked in the use of such phrases as "innocent children" ("Teachers' Strike Cripples Schools", Tue July 1 2008:2), "expose our children to unwarranted turmoil" (Abubakar and Awoyale, Mon June 30 2008:2). These rhetorical strategies seemed to have achieved their targets in favour of the newspaper and the power elite since the strike was called off and the TSS remained a mirage.

\section{CONCLUSION}

We argued in this paper that the media has the potentials to subtly project and legitimize dominant ideological positions by exploiting certain strategic rhetorical appeals that can exert untold and damaging consequences on those affected by them. The work adopts a critical approach to power inequality as it is expressed, constituted, naturalized, legitimized and sustained by discourse. Meaning is said to reside in the systemic patterns of choice and our lexical and grammatical choices, whether implicit or explicit, are predetermined by our various ideologies.

Our textual data in this case study was implicated in hiding under the ideology of silence, exploiting intertextual resources, attribution to sources and gatekeeping ideology to shroud its ulterior motive of projecting the views of the power elite while feebly making a show of acting out its watchdog role. We argue that it is only when our critical discourse awareness is raised to such a level that both producers and consumers of discourse, begin to debunk, demystify and deconstruct discourses that reinforce asymmetries and repression so as to subvert them, then and only then can our discourses become emancipatory. In the present circumstances, that level of linguistic consciousness remains illusory.

\section{FUNDING ACKNOWLEDGEMENT}

The manuscript for this publication was prepared with the support of an African Humanities Program, (AHP) Fellowship, established by the American Council of Learned Societies (ACLS) and supported financially by the Carnegie Corporation of New York

\section{REFERENCES}

\section{Books and Journals}

[1] Robinson, M. 2007. Chambers $21^{\text {st }}$ Century Dictionary. Revised ed. Allied Chambers.

[2] Crystal, D.. 2003. A Dictionary of Linguistics and Phonetics. 5th ed. Blackwell, Malden, MA.

[3] Carlin, Prentice. Diana and James Payne. 1995. Public Speaking Today. 2nd ed. National Textbook Company.

[4] Eggins, S. 2004. An Introduction to Systemic Functional Linguistics. 2nd ed. Continuum.

[5] Elly, I. 2009. Newspaper headlines and relevance: Adhoc concepts in adhoc contexts. Journal of Pragmatics. 41(4). 699-720

[6] Fairclough, N. 1995. Critical Discourse Analysis: The Critical Study of Language. Longman

[7] Halliday, M. A.K. 1978. Language as Social Semiotic. The Social Interpretation of Language and Meaning. Edward Arnold

[8] Halliday, M.A. K. and Matthiessen, C. M. M. 2004. An Introduction to Functional Grammar. 3rd ed. Hodder Arnold.

[9] Jones, J. and Wareing, S. 2000. Language and politics. In L. Thomas \& S. Wareing, eds. Language, Society and Power:An Introduction, Routlegde. 31-47.

[10] Luke, A. 2008. Theory and practice in critical discourse analysis. In L. Saha, ed International Encyclopedia of the Sociology of Education, .1-11. Elsevier Science,.

[11] Mey, J. L. 200.1 Pragmatics: An Introduction. Blackwell.

[12] Oxford Advanced Learners' Dictionary: International Student's Edition 2005.

[13] Trail, V. G. 2004. Rhetorical Terms and Concepts: A Contemporary Glossary. Spectrum Books Ltd.

[14] Van Dijk, T. A. 2005. Multidisciplinary CDA: A plea for diversity. In R. Wodak and M. Meyer. Methods of Critical Discourse Analysis, Sage.95-120.

[15] Watson, J and Hill, A. 2006. Dictionary of Media and Communication Studies. $7^{\text {th }}$ ed. Hodder Arnold.

[16] Wodak, R. 2002. Aspects of critical discourse analysis. Online, http://www.unikoblenz.deldiekmann/zfalarchiv/zfal36/.pdf. (Accessed July 30 2008).

[17] Wodak, R. \& B. Busch. 2004. Approaches to media texts. In J. Downing et al. Handbook of Media Studies, Sage.105123.

\section{Newspaper Articles}


[18] Abubakar, M. 2008. Retreat reveals background of teachers' salary structure. The Guardian, (July 3, 2008$), 60$.

[19] Abubakar, M, and Awoyale, F. 2008. Govt. maintains stance, teachers begin strike today. The Guardian, (June 30, 2008), 1.

[20] Abuh, A. 2008. Private school owners decry harassment by NUT. The Guardian, (July 1, 2008), 9.

[21] Akhaine, S. 2008. Teachers protest in Kaduna, Ask govt to meet demands. The Guardian, (July 28, 2008$), 8$.

[22] Editorial. The proposed health workers' strike. 2008. The Guardian, (July 30, 2008), 18

[23] Fanimo, D, T. Omofoye \& M. Njadvara. 2008. Teachers suspend strike. The Guardian, (July 30, 2008$), 1$.

[24] Ijediogor, G., Abuh, A., Njoku, L., Oladimeji, D., T. Omoloye, T., and Ojo, O. 2008. Stakeholders groan under the effect of the strike. The Guardian, (July 26, 2008), 50-53.

[25] Jimoh, M.A., S. Nwakaudu, O.A. Aliu and R. Salau 2008. Senate panel to meet Yar'Adua on teachers' strike. The Guardian, (July 4, 2008), 1.

[26] Labour, senate panel decry govt's action over teachers' strike. 2008. The Guardian, (July 23, 2008$), 80$.

[27] NUT strike: NLC urges YarAdua's intervention. 2008. The Guardian, (July 24, 2008), 35-36.

[28] Nwakaudu, S. and Ogiji, J. 2008. Minister, NUT differ on teachers' strike. The Guardian, (July 22, 2008$), 112$.

[29] Ogunibe, O. 2008. Letters: The teachers' strike. The Guardian, (July 22, 2008), 18.

[30] Onuorah, M. 2008. VP, Govs, others invite teachers to fresh talks. The Guardian, (July 18, 2008), 3.

[31] Onuorah, M., Ogbodo, J, Abubakar, M., Jimoh, M.A., Olayinka, C. and Abuh, A. 2008. Govt warns NUT against closure of private schools The Guardian, (July 3, 2008), 1.

[32] Onuorah, M., Abubakar, M., Dako, T., Fagbemi, A., Omofoye, T., and Alabi, J. (2008). Teachers down tools, government rules out talks. NECO shifts exams. The Guardian, (June 12,2008), 1.

[33] Olayinka, C. 2008. Teachers seek removal of Education Minister, suspend strike" The Guardian, (July 14, 2008$), 2$.

[34] Oropo, K. T. 2008. Teachers are right to demand uniform salary, says Fasehun. The Guardian, (July 27, 2008$), 6$.

[35] Ozioruva, A.O., C. Collins, I. Nejuvie, F. Ugwuoke \& I. Ayandare 2008. When teachers insist on their rewards on earth... The Guardian, (July18, 2008), 30-31.

[36] Popoola, I. 2008. Placating teachers back to class. The Guardian, (July 22, 2008), 39.

[37] Soloki, G. 2008. Why the Minister of Education must go. The Guardian, (July 24, 2008), 79.

[38] Teachers' strike cripples schools. 2008. The Guardian, (July1 2008), 1-2.

[39] Teachers' strike stalls release of NABTEB results. 2008. The Guardian, (July 26, 2008), 1.

\section{Author' biography with Photo}

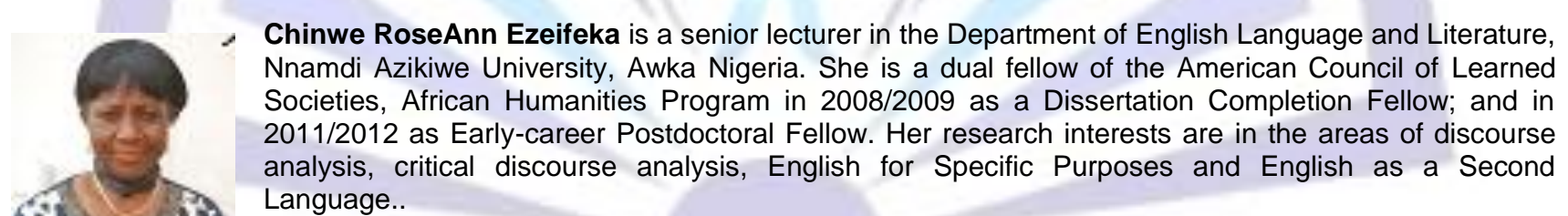

